(c) 2018 - ISSN 1807-2577

\title{
Virulence factors of Candida species from the oral mucosa and prostheses of elderly people from a riverside community in the Amazon state, Brazil
}

\author{
Fatores de virulência de espécies de Candida provenientes da mucosa oral e \\ das próteses dos idosos de uma comunidade ribeirinha no Amazonas - Brasil
}

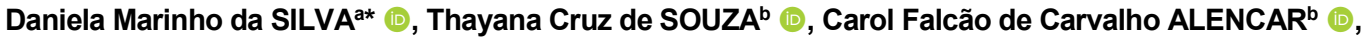 \\ Ingrid da Silva de SOUZA ${ }^{\mathrm{b}}$ (1), Maria Fulgência Costa Lima BANDEIRA ${ }^{\mathrm{a}} \mathbb{1}^{\mathbb{D}}$, \\ Ormezinda Celeste Cristo FERNANDES ${ }^{\text {b }}$ (1)
}

aUFAM - Universidade Federal do Amazonas, Faculdade de Odontologia, Manaus, AM, Brasil

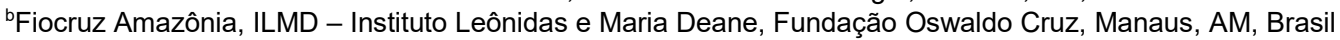

How to cite: Silva DM, Souza TC, Alencar CFC, Souza IS, Bandeira MFCL, Fernandes OCC. Virulence factors of Candida species from the oral mucosa and prostheses of elderly people from a riverside community in the Amazon state, Brazil. Rev Odontol UNESP. 2019;48:e20190094. https://doi.org/10.1590/1807-2577.09419

\begin{abstract}
Resumo
Introdução: A Candida albicans é a levedura que mais acomete a cavidade oral, podendo causar infecção. Porém diversos fatores podem estar associados ao aparecimento da candidíase, que podem estar relacionados com a higiene e saúde dos indivíduos, mas também com a patogenicidade destes microrganismos. Objetivo: Avaliar os fatores de virulência de leveduras do gênero Candida isoladas da mucosa oral dos idosos residentes na Comunidade Lago do Limão - Iranduba - Amazonas - Brasil. Material e método: Foram realizados os testes de urease, proteinase, fosfolipase, e avaliação da produção de hemólise. Na análise estatística utilizou-se teste Exato de Fisher e Quiquadrado. Resultado: Obteve-se a prevalência de espécies não-albicans, quanto aos fatores de virulência, todos os isolados foram ureases negativos, houve prevalência de produção muito forte de proteinase, enquanto que no teste da fosfolipase, a maioria dos isolados não apresentou produção desta enzima; todas as leveduras analisadas apresentaram produção de hemolisina, sendo mais prevalente a hemólise grau IV. Não houve diferença estatisticamente significativa entre a virulência dos isolados oriundos da cavidade oral e da prótese dos idosos analisados. Conclusão: Diversos fatores de virulência podem apresentar-se com alta intensidade na presença de alterações da microbiota oral. Além disso, as espécies não-albicans apresentam fatores de virulência tanto quanto a C. albicans, com graus de patogenicidade elevados. Este estudo permite a análise de estratégias de prevenção da candidíase, com intuito de promover melhor saúde e qualidade de vida para os idosos.
\end{abstract}

Descritores: Candida; mucosa oral; prótese dentária; virulência.

\begin{abstract}
Introduction: Candida albicans is the yeast most commonly affecting the oral cavity, sometimes causing infection. However, several factors may be associated with the onset of candidiasis, which may be related not only to the hygiene and health of individuals, but also to the pathogenicity of these microorganisms. Objective: To evaluate the virulence factors of Candida yeasts isolated from the oral mucosa of elderly people living in the "Comunidade Lago do Limão", municipality of Iranduba, Amazonas state, Brazil. Material and method: Testes were performed to assess the production of urease, proteinase, phospholipase and hemolysin. Statistical analysis used the Fisher's exact test and the Chi-squared test. Result: Prevalence of non-albicans species was observed. As for virulence factors, all isolates were negative ureases, and there was prevalence of very strong proteinase production, whereas most isolates did not produce this enzyme in the phospholipase test. All yeasts analyzed presented hemolysin production, with grade IV hemolysis as the most prevalent. There was no statistically significant difference between the virulence of isolates from
\end{abstract}


the oral cavity and the prostheses of the elderly analyzed. Conclusion: Several virulence factors may present with high intensity in the presence of oral microbiota changes. In addition, non-albicans species present number of virulence factors similar to that of $C$. albicans, with high pathogenicity. This study allows a better analysis of candidiasis prevention strategies aiming to promote improvement in the health and quality of life for the elderly.

Descriptors: Candida; oral mucosa; dental prosthesis; virulence.

\section{INTRODUCTION}

Several physiological and metabolic changes of systemic order and in the oral cavity occur during aging. The use of dental prostheses that favor the colonization of $C$. albicans by altering the oral microbiota lead to the emergence of candidiasis ${ }^{1-4}$.

Candidiasis is an infectious process caused by fungi of genus Candida. This microorganism has a commensal relationship with the host, but when there is an imbalance in this flora, it can become pathogenic, affecting approximately $10 \%$ of elderly people with poor health. Candida albicans is the species most commonly associated with infection, accounting for over $80 \%$ of the fungi isolated from the oral cavity5,6.

Manifestations of oral candidiasis are classified as acute or chronic, with the latter being found more frequently in the elderly. The acute manifestation is pseudomembranous and erythematous, whereas the chronic manifestation presents lesions such as chronic hyperplasia, prosthetic stomatitis, medial rhomboid glossitis, angular cheilitis, and hairy tongue ${ }^{5,6}$.

Prosthetic stomatitis is an infectious process that affects the palatal mucosa in close contact with the prosthesis. It has a multifactorial etiology and may also be associated with poor hygiene of the prostheses with consequent biofilm accumulation ${ }^{7}$.

However, not only host-related factors can cause candidiasis, but also the virulence factors of these microorganisms, including secretion of hydrolytic enzymes (phospholipases and proteinases), toxins, hemolysins, and adhesion and biofilm formation capacity8-10.

Colonization by fungi of the genus Candida in the human oral microbiota may cause some diseases when the patient immune system is weakened, resulting in local or even systemic impairment.

These facts demonstrate the clinical relevance of the analysis of the main virulence factors of Candida species, highlighting the knowledge of these mechanisms involved in the pathophysiology of candidiasis, which may provide prevention and treatment strategies.

\section{MATERIAL AND METHOD}

Forty isolates of Candida yeast from the palate and prostheses of elderly people residing in the "Comunidade Lago do Limão", municipality of Iranduba, Amazonas state, Brazil, were used in this study. The samples were collected for a master's thesis entitled Oral health conditions of the elderly population in a rural community of Amazonas state (process no. CEP 61618016.0.0000.5020) and transferred to the Amazon Fungi Collection of "Instituto Leônidas e Maria Deane" (CFAM-ILMD-FIOCRUZ-Amazonia). The isolates were previously identified by CHROMagar Candida ${ }^{\circledR}$ chromogenic medium (BioMerieux, France), a presumptive method for identifying Candida, and stored under refrigeration at $20{ }^{\circ} \mathrm{C}$ in Saboraud Agar (K25-610103-Kasvi, Italy) with glycerol as a wall protector.

The virulence factors of these yeasts were evaluated through production of urease, proteinase, phospholipase and hemolysin tests. For the urease test, isolates were reactivated and seeded in 
Christensen ${ }^{11}$ agar medium (Urea Agar) and soon after incubated at $37^{\circ} \mathrm{C}$ with daily observation for seven days. A change in medium color to fuchsine-red is indicative of a positive result, otherwise the culture is negative. After seven days of incubation, the result was read.

The study of proteinase production was performed according to the methodology described by Teixeira et al. ${ }^{12}$, in which the test medium consisted of sterile plates containing agar, gelatin and skimmed milk, diluted in Citrate-Phosphate Buffer solution ( $\mathrm{pH}$ 5.0).

Phospholipase production was analyzed according to the egg yolk plate method described by Price et al..$^{13}$ with modifications, where the medium consisted of Sabouraud Dextrose Agar plus sodium chloride, calcium chloride, and yeast extract. After sterilization of the medium, $30 \%$ egg yolk emulsion was aseptically added.

For enzymatic analysis, yeast fragments with $24 \mathrm{~h}$ of growth were inoculated on the surface of the specific medium for each enzyme investigated, and incubated for seven days at $37 \stackrel{\circ}{\circ}$. Enzyme production was observed by the formation of transparent and opaque halos around the yeast colony for proteinase and phospholipase, respectively.

The tests were performed in triplicate and the precipitation zone value $(\mathrm{Pz})$ was given as the mean of the evaluated diameters (colony/halo+colony). Production was classified according to the $\mathrm{Pz}$ value as very strong ++++ $(\mathrm{Pz} \leq 0.69)$, strong +++ (Pz between 0.70 and 0.79$)$, average ++ (Pz between 0.80 and 0.89), or weak + (Pz between 0.90 and 0.99).

The hemolysin production test was performed according to the method by Malpezzi et al. ${ }^{14}$; Berlinck et al. ${ }^{15}$; Costa-Lotufo et al. ${ }^{16}$ with modifications as follows: sheep blood was diluted in saline $(0.85 \% \mathrm{NaCl}+10 \mathrm{mM} \mathrm{CaCl} 2)$, washed three to four times in saline, and then centrifuged (1500 rpm/10 $\mathrm{min})$. An erythrocyte pellet was obtained and resuspended in saline to prepare the $2 \%$ erythrocyte solution (ES). The test was performed using 96-well microplates containing $150 \mu \mathrm{L}$ of yeast solution and an additional $150 \mu \mathrm{L}$ of ES. The negative control was obtained with $0.2 \%$ DMSO-Dimethyl sulfoxide, whereas the positive control was obtained with $0.2 \%$ Triton X-100.

After this process, the samples were incubated for 1 hour under constant agitation at room temperature $\left(26^{\circ} \mathrm{C}\right)$ and then centrifuged at $1500 \mathrm{rpm} / 10 \mathrm{~min}$. Reading of the results was classified according to the hemolysis intensity compared with the control as grade I (without hemolysis), II (weak), III (strong), and IV (very strong) hemolysis.

Data were processed using R 3.6.0 and Rstudio 1.1.4, with various packages (tidyverse, epiDisplay, gridExtra, and sjPlot) ${ }^{17}$. A significance level of 0.05 was adopted in all statistical analyses.

The Fisher's Exact and Chi-squared tests were used to analyze the relationship between the "Experiment Location" and the qualitative (categorical) variables.

As test hypotheses, we used H0: the variables are independent; H1: the variables are dependent. Decision Rule: Reject H0 if $p$-value is $<0.05$.

\section{RESULT}

The 40 yeasts analyzed ( 21 from samples collected from the mouth (palate) and 19 from the prostheses) in the elderly from "Comunidade Lago do Limão", municipality of Iranduba, showed prevalence of $80 \%$ Candida non-albicans species, and $21 \%$ of isolates originating from the palate of the elderly analyzed (Table 1). 
Table 1. Correlation between Candida species and pathogenicity tests with the origin of the samples collected from elderly people in the "Comunidade do Lago do Limão", municipality of Iranduba, Amazonas state, Brazil

\begin{tabular}{|c|c|c|c|}
\hline \multirow{3}{*}{ Variables } & \multicolumn{2}{|c|}{ Experiment Location } & \multirow[b]{2}{*}{$p$-value } \\
\hline & MT & PT & \\
\hline & $\mathrm{n}=21(\%)$ & $\mathrm{n}=19(\%)$ & \\
\hline PROTEINASE & & & 0.342 \\
\hline Very Strong & $12(57.1)$ & $8(42.1)$ & \\
\hline NEG & $9(42.9)$ & $11(57.9)$ & \\
\hline PHOSPHOLIPASE & & & 0.873 \\
\hline Very Strong & $6(28.6)$ & $5(26.3)$ & \\
\hline NEG & $15(71.4)$ & $14(73.7)$ & \\
\hline HEMOLISIN & & & 0.698 \\
\hline GRADE III & $5(23.8)$ & $3(15.8)$ & \\
\hline GRADE IV & $16(76.2)$ & $16(84.2)$ & \\
\hline SPECIES & & & 0.28 \\
\hline C. albicans & $3(14.3)$ & $3(15.8)$ & \\
\hline C. glabrata & $7(33.3)$ & $4(21.1)$ & \\
\hline C. krusei & 7 (33.3) & $3(15.8)$ & \\
\hline C. parapsilosis & $2(9.5)$ & $7(36.8)$ & \\
\hline C. tropicalis & $2(9.5)$ & $2(10.5)$ & \\
\hline
\end{tabular}

Captions: MT - mouth, PT - prosthesis. $p$-value of Chi-squared test or Fisher's Exact test. Percentage given by column. Significance level of 0.05 .

The results presented in Table 1 showed no evidence according to the $p$-values (none $<0.05$ ) found to reject the independence hypothesis.

In the virulence tests, the isolates did not present urease production. However, analysis of the production of hydrolytic enzymes showed prevalence of isolates collected from the mouth of the elderly with positive results for proteinase $(57.1 \%)$, being classified as very strong, whereas prevalence of negative results (71.4\%) was observed in the phospholipase test.

In this study, all isolates of Candida sp. found hemolysin production, with prevalence of grade IV hemolysis in samples from the prostheses of the elderly people (84.2\%).

The species with the highest production of proteinases was C. glabrata, followed by C. krusei. In the phospholipase test, of the isolates that tested positive, $C$. parapsilosis showed the highest production. However, in the hemolysin test, all species analyzed had hemolytic potential, especially C. parapsilosis and C. krusei as major causes of grade IV hemolysis. Comparisons between the virulence tests and the Candida species found in the study are depicted in Figures 1, 2 and 3 , respectively. 


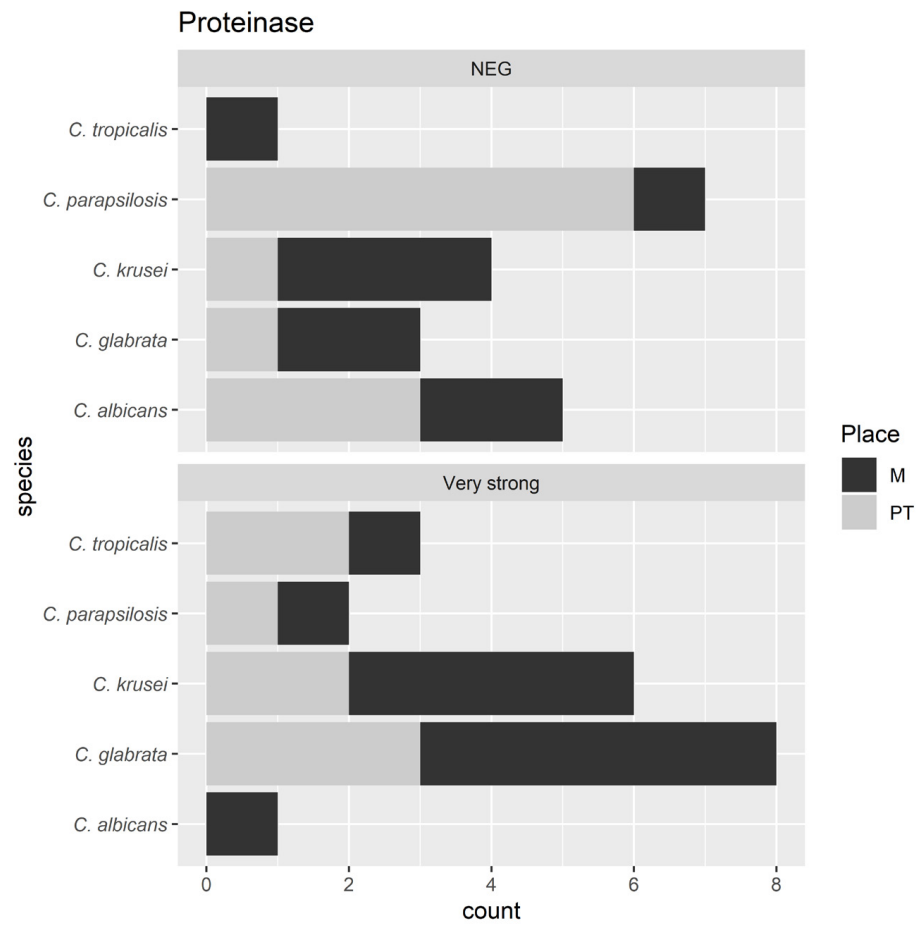

Figure 1. Proteinase-producing Candida species as virulence factor derived from isolates of the mouth and prostheses of the elderly from "Comunidade Lago do Limão", municipality of Iranduba, Amazonas state, Brazil.

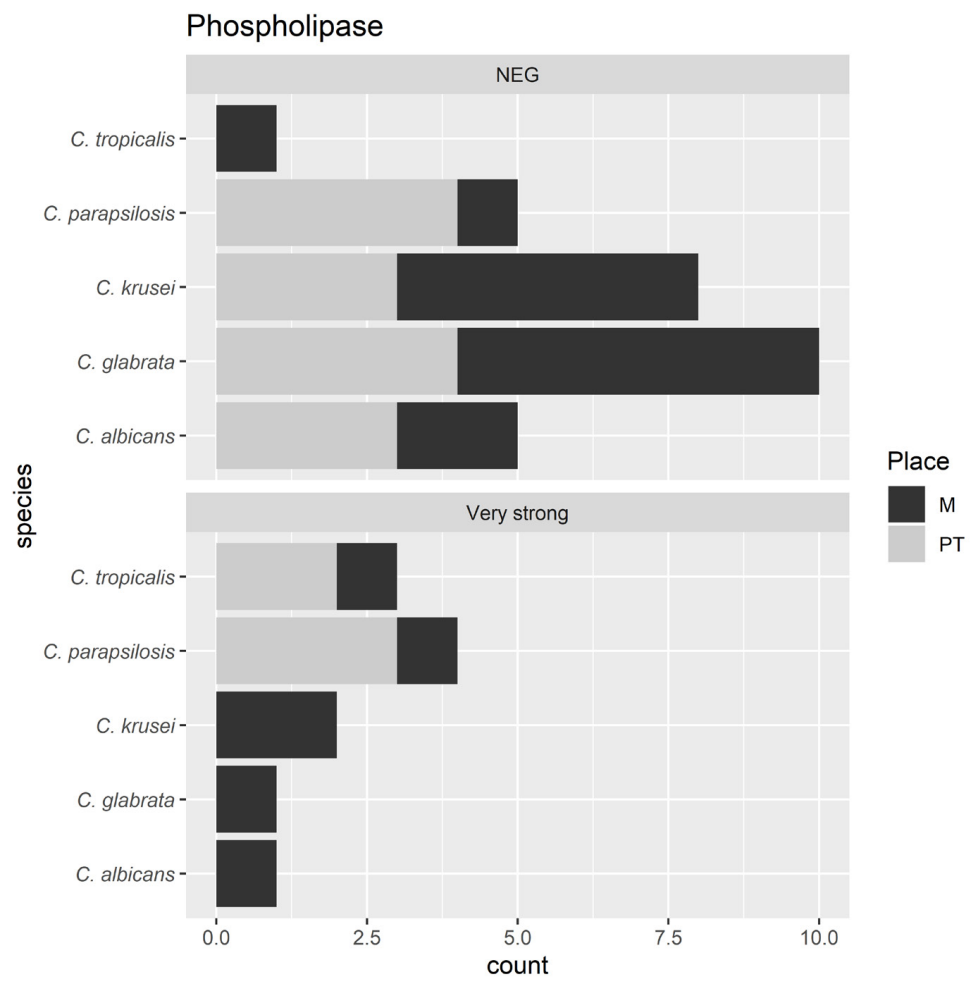

Figure 2. Phospholipase-producing Candida species as virulence factor derived from isolates of the mouth and prostheses of the elderly from "Comunidade Lago do Limão", municipality of Iranduba, Amazonas state, Brazil. 


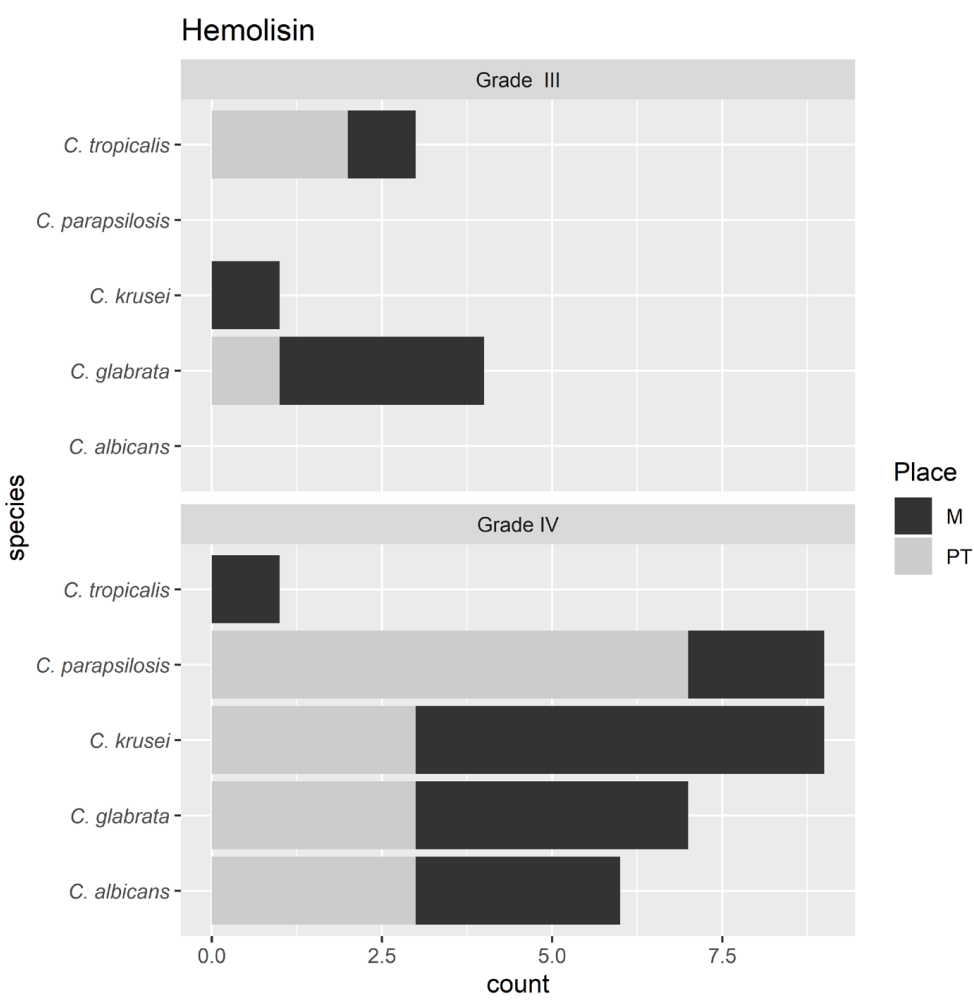

Figure 3. Hemolysin-producing Candida species as virulence factor derived from isolates of the mouth and prostheses of the elderly from "Comunidade Lago do Limão", municipality of Iranduba, Amazonas state, Brazil.

\section{DISCUSSION}

Despite the fact that Candida albicans is the yeast species that most affects the oral cavity, thus being the most pathogenic, the present study revealed a predominance of pathogenicity among non-albicans species, in line with the study conducted by Mohandas, Ballal ${ }^{18}$ with hospitalized patients in southern India.

Some pathogenic fungi are able to produce urease to use urea as a source of nitrogen, but as a result of the breakdown reaction of urea, ammonia, a toxic substance to host cells, can cause the immune system to evade and, consequently, promote infection. A study by Seeliger ${ }^{19}$ tested the 14 Candida species to identify urease production, but only one Candida humicola culture showed a positive result. However, studies have stated that most yeast species responsible for causing pathogens in humans are negative urease ${ }^{20}$.

Other virulence factors that Candida species may exhibit are the production of proteinases and phospholipases that facilitate the invasion of hyphae into the epithelium. In the case of proteinase, host protein degradation occurs by hydrolysis of peptide bonds, both those located on the mucosal surface and those related to the immune system (immunoglobulin, complement system proteins, and cytokines); and in the presence of phospholipases, phospholipid hydrolysis occurs resulting in the disintegration of cell membranes ${ }^{8,9,21}$.

Results of this study corroborate those by D'Eça et al. ${ }^{21}$, who found that $50 \%$ of the yeasts showed proteinase activity. However, in the study by Andreola et al. ${ }^{9}$, approximately $97 \%$ of Candida spp. were positive for proteinase. Regarding Candida species, studies ${ }^{21}$ have shown prevalence of $64.2 \%$ of very strong proteinase activity by Candida albicans isolates, and even proteinase production by $100 \%$ of $C$. albicans isolates, whereas only $25 \%$ of isolates from non-albicans species obtained positive results 22 . 
In the phospholipase test, there were difference between the results obtained in the study and those by D'Eça et al. ${ }^{21}$, who reported activity in $68.3 \%$ of Candida spp. and $76.6 \%$ prevalence of C. albicans, as well as those by Martins et al.23, who verified that all isolates were phospholipase positive; however, only $43 \%$ of the non-albicans species presented phospholipase production. In contrast, the results of this study were similar to those observed by Mohandas, Ballal ${ }^{18}$, who found higher phospholipase production in non-C. albicans species, differing only in their prevalence $-44.1 \%$ of the isolates.

Nevertheless, although $C$. albicans is the most pathogenic species, studies have shown a considerable increase of non-albicans species involved in infectious processes, which may lead to systemic infection in debilitated patients ${ }^{8}$.

Candida fungi may also present hemolytic capacity, aiming to obtain iron from the host tissues for their metabolism through erythrocyte lysis, with hemoglobin being of great importance in this process. The oral cavity is rich in iron from both lactoferrin (a protein present in saliva) and ferritin (intracellular), facilitating the invasion of hyphae and possibly leading to systemic candidiasis ${ }^{22}$.

Regarding the hemolysin production test, the study by Rossoni et al. ${ }^{22}$ indicated predominance of $100 \%$ Candida albicans in the production of this protein, thus being an important virulence factor responsible for causing systemic infections. However, the comparison between the hemolytic activity developed by non-albicans species and C. albicans showed no statistically significant difference, being characterized with the same hemolytic potential. Prevalence of hemolysin-producing non-albicans species was observed by Pakshir et al. ${ }^{24}$ in a study with clinical analyses of Candida species.

In all associations tested in Table 1, no statistical dependence was found between the virulence factors and the fungi collected from the oral cavity and prostheses of elderly people from the "Comunidade Lago do Limão", municipality of Iranduba, Amazonas state, Brazil, thus accepting the $\mathrm{H}_{0}$ hypothesis, that is, the variables are not dependent.

\section{CONCLUSION}

Based on the methodology used, we conclude that Candida yeasts have several virulence factors that may present with high intensity in the presence of oral microbiota changes. Regarding the comparison between the Candida species analyzed, it was found that non-albicans species present number of virulence factors similar to that of $C$. albicans, with high pathogenicity, and may even resemble them with respect to infectious potential.

The study of host-related factors, as well as virulence factors in Candida species, allows a better analysis of candidiasis prevention strategies in order to promote improvement in the health and quality of life of these elderly people.

\section{ACKNOWLEDGEMENTS}

The author is sincerely grateful to everyone who contributed to the execution of this study, especially to Dr. Ormezinda Fernandes (advisor) and Professor Maria Fulgência Bandeira for all their support, as well as to Carol Falcão for kindly providing me with her master's thesis collection samples, and to Ingrid Souza and Thayana Souza for assisting with the pathogenicity tests. The author also thanks Fiocruz Amazônia/ILMD for investing in health research and providing opportunities for enhancing knowledge and "Fundação de Amparo à Pesquisa do Estado do Amazonas" (FAPEAM) for the funding received. 


\section{REFERENCES}

1. Johnson KN, Botros DB, Groban L, Bryan YF. Anatomic and physiopathologic changes affecting the airway of the elderly patient: implications for geriatric-focused airway management. Clin Interv Aging. 2015 Dec 4;10:1925-34. http://dx.doi.org/10.2147/CIA.S93796.

2. Fávero Bulgarelli A, Pinto IC, Rodrigues L Jr, Manço ARX. Estudo das queixas sobre saúde bucal em uma população de idosos na cidade de Ribeirão Preto-SP. Rev Bras Geriatr Gerontol. 2009;12(2):175-91. http://dx.doi.org/10.1590/1809-9823.2009.12022.

3. Bianchi CM, Bianchi HA, Tadano T, Paula CR, Hoffmann-Santos HD, Leite DP Jr, et al. Factors related to oral candidiasis in elderly users and non-users of removable dental prostheses. Rev Inst Med Trop São Paulo. 2016;58:17. http://dx.doi.org/10.1590/S1678-9946201658017. PMid:27007560.

4. Antinori S, Milazzo L, Sollima S, Galli M, Corbellino M. Candidemia and invasive candidiasis in adults: a narrative review. Eur J Intern Med. 2016 Oct;34:21-8. http://dx.doi.org/10.1016/j.ejim.2016.06.029. PMid:27394927.

5. Lewis MAO, Williams DW. Diagnosis and management of oral candidosis. Br Dent J. 2017 Nov;223(9):675-81. http://dx.doi.org/10.1038/sj.bdj.2017.886. PMid:29123282.

6. Laurent M, Gogly B, Tahmasebi F, Paillaud E. Oropharyngeal candidiasis in elderly patients. Geriatr Psychol Neuropsychiatr Vieil. 2011 Mar;9(1):21-8. http://dx.doi.org/10.1684/pnv.2011.0259. PMid:21586373.

7. Kilic K, Koc AN, Tekinsen FF, Yildiz P, Kilic D, Zararsiz G, et al. Assessment of Candida species colonization and denture-related stomatitis in bar- and locator-retained overdentures. J Oral Implantol. 2014 Oct;40(5):549-56. http://dx.doi.org/10.1563/AAID-JOI-D-12-00048. PMid:25295886.

8. Giolo MP, Svidzinski TIE. Fisiopatogenia, epidemiologia e diagnóstico laboratorial da candidemia. J Bras Patol Med Lab. 2010;46(3):225-34. http://dx.doi.org/10.1590/S1676-24442010000300009.

9. Andreola P, Demathé A, Galafassi D, Elsemann EB, Elsemann RB, Gazzoni AF. Estudo comparativo entre a produção de fosfolipases extracelulares e proteinases do gênero Candida isoladas a partir de infecções de cavidade oral. Rev Odontol UNESP. 2016 Aug;45(4):219-26. http://dx.doi.org/10.1590/1807-2577.26115.

10. da Silva-Rocha WP, Lemos VL, Svidizisnki TIE, Milan EP, Chaves GM. Candida species distribution, genotyping and virulence factors of Candida albicans isolated from the oral cavity of kidney transplant recipients of two geographic regions of Brazil. BMC Oral Health. 2014 Mar;14(1):20. http://dx.doi.org/10.1186/1472-6831-14-20. PMid:24628850.

11. Christensen WB. Urea decomposition as a means of differentiating proteus and paracolon cultures from each other and from Salmonella and Shigella types 1. J Bacteriol. 1946 Oct;52(4):461-6. PMid:16561200.

12. Teixeira MFS, Silva TA, Carneiro ALB, Palheta RA, Atayde HM. Fungos da Amazônia: uma riqueza inexplorada (aplicações biotecnológicas). Manaus: Edua; 2011. 255 p.

13. Price MF, Wilkinson ID, Gentry LO. Plate method for detection of phospholipase activity in Candida albicans. Sabouraudia. 1982 Mar;20(1):7-14. http://dx.doi.org/10.1080/00362178285380031. PMid:7038928.

14. Malpezzi EL, de Freitas JC, Muramoto K, Kamiya H. Characterization of peptides in sea anemone venom collected by a novel procedure. Toxicon. 1993 Jul;31(7):853-64. http://dx.doi.org/10.1016/00410101(93)90220-D. PMid:8105563.

15. Berlinck RG, Ogawa CA, Almeida AM, Sanchez MA, Malpezzi EL, Costa LV, et al. Chemical and pharmacological characterization of halitoxin from Amphimedon viridis (Porifera) from the southeastern Brazilian coast. Comp Biochem Physiol C Pharmacol Toxicol Endocrinol. 1996 Oct;115(2):155-63. http://dx.doi.org/10.1016/S0742-8413(96)00107-7. PMid:9568363. 
16. Costa-Lotufo LV, Cunha GM, Farias PA, Viana GS, Cunha KM, Pessoa C, et al. The cytotoxic and embryotoxic effects of kaurenoic acid, a diterpene isolated from Copaifera langsdorffii oleo-resin. Toxicon. 2002 Aug;40(8):1231-4. http://dx.doi.org/10.1016/S0041-0101(02)00128-9. PMid:12165328.

17. Laboratório de Estatística e Geoinformação - LEG. Sofware: material-r - Wiki do LEG [Internet]. Curitiba: UFPR; 2011 [citado 16 de setembro de 2019]. Disponível em: http://www.leg.ufpr.br/doku.php/sofware:material-r

18. Mohandas V, Ballal M. Distribution of Candida Species in different clinical samples and their virulence: biofilm formation, proteinase and phospholipase production: a study on hospitalized patients in Southern India. J Glob Infect Dis. 2011 Jan;3(1):4-8. http://dx.doi.org/10.4103/0974-777X.77288. PMid:21572601.

19. Seeliger HP. Use of a urease test for the screening and identification of cryptococci. J Bacteriol. 1956 Aug;72(2):127-31. PMid:13366888.

20. Rutherford JC. The emerging role of urease as a general microbial virulence factor. PLoS Pathog. 2014 May 15;10(5):1-3. http://dx.doi.org/10.1371/journal.ppat.1004062.

21. D’Eça A Jr, Silva AF, Rosa FC, Monteiro SG, Maria Silva Figueiredo P, Andrade Monteiro C. In vitro differential activity of phospholipases and acid proteinases of clinical isolates of Candida. Rev Soc Bras Med Trop. 2011;44(3):334-8. http://dx.doi.org/10.1590/S0037-86822011005000036. PMid:21901875.

22. Rossoni RD, Barbosa JO, Vilela SF, Jorge AO, Junqueira JC. Comparison of the hemolytic activity between C. albicans and non-albicans Candida species. Braz Oral Res. 2013 Nov-Dec;27(6):484-9. http://dx.doi.org/10.1590/S1806-83242013000600007. PMid:24346046.

23. Martins JS, Junqueira JC, Faria RL, Santiago NF, Rossoni RD, Colombo CE, et al. Antimicrobial photodynamic therapy in rat experimental candidiasis: evaluation of pathogenicity factors of Candida albicans. Oral Surg Oral Med Oral Pathol Oral Radiol Endod. 2011 Jan;111(1):71-7. http://dx.doi.org/10.1016/j.tripleo.2010.08.012. PMid:21176823.

24. Pakshir K, Zomorodian K, Karamitalab M, Jafari M, Taraz H, Ebrahimi H. Phospholipase, esterase and hemolytic activities of Candida spp. isolated from onychomycosis and oral lichen planus lesions. J Mycol Med. 2013 Jun;23(2):113-8. http://dx.doi.org/10.1016/j.mycmed.2013.04.007. PMid:23706304.

\section{CONFLICTS OF INTERESTS}

The authors declare no conflicts of interest.

\section{${ }^{*}$ CORRESPONDING AUTHOR}

Daniela Marinho da Silva, UFAM - Universidade Federal do Amazonas, Faculdade de Odontologia, Av. Ministro Waldemar Pedrosa, 1539, Praça 14, 69025-050 Manaus - AM, Brasil, e-mail: daniela.marinhodasilva@yahoo.com.br

Received: September 29, 2019

Accepted: October 9, 2019 